\title{
HUBUNGAN PENGEMBANGAN KARYAWAN DENGAN PRESTASI KERJA PADA PT. BANK CENTRAL ASIA TBK. CABANG BENGKULU
}

\author{
Nia Indriasari \\ Program Studi Manajemen \\ Fakultas Ekonomi dan Bisnis Universitas Bengkulu
}

\begin{abstract}
ABSTRAK
Nia Indriasari; Hubungan Pengembangan Karyawan dengan Prestasi kerja pada PT. Bank Central Asia Tbk. Cabang Bengkulu. Tujuan penelitian ini adalah untuk mengetahui hubungan antara pengembangan karyawan dengan Prestasi kerja pada PT. Bank Central Asia Tbk. Cabang Bengkulu. Populasi dalam penelitian ini adalah seluruh karyawan pada PT. Bank Central Asia Tbk. Cabang Bengkulu sebanyak 56 orang yang berstatus sebagai karyawan tetap. Metode pengambilan sampel pada penelitian ini adalah dengan menggunakan metode Sensus. Metode pengumpulan data dalam penelitian ini adalah metode kuesioner, sedangkan metode analisis menggunakan analisis distibusi rata-rata, korelasi rank spearman, dan pengujian hipotesis. Dari perhitungan koefisien korelasi, nilai $\rho$ hitung $=0,91$ artinya hubungan variabel pengembangan dengan kinerja karyawan pada PT. Bank Central Asia Tbk. Cabang Bengkulu adalah sangat kuat. Dari uji hipotesis diperoleh nilai $t$ hitung lebih besar dari $t$ tabel yaitu nilai $t$ hitung $=18,73$ sedangkan $t$ tabel $=2,003$, artinya ada hubungan signifikan antara pengembangan dengan kinerja karyawan pada PT. Bank Central Asia Tbk. Cabang Bengkulu.
\end{abstract}

\begin{abstract}
Nia Indriasari; This study aims to determined the relationship between the development of employees with performance at PT. Bank Central Asia Tbk. Bengkulu branch. The method used in this study are: qualitative and quantitative analysis using the average distribution analysis, and the Spearman rank correlation test hypotheses. From the calculation of the correlation coefficient, calculated value $=0.91$ means the variable relationship with employee performance development at PT. Bank Central Asia Tbk. Bengkulu branch is very strong. Hypothesis tests obtained $t$ value greater than $t$ table is $t$ value $=18.73$ whereas $t$ table $=2.003$, meaning that if there is a significant relationship between the development of the performance of employees at PT. Bank Central Asia Tbk. Bengkulu branch. Employees at PT. Bank Central Asia Tbk. Bengkulu branch has an interest in any development training held by PT. Bank Central Asia Tbk. Bengkulu branch, employees at PT. Bank Central Asia Tbk. Branch has a high creativity in carrying out the tasks given by PT. Bank Central Asia Tbk. Bengkulu branch so that the creativity that is owned by the employee, the employee is able to improve the quality of work from time to time which can improve the performance of PT. Bank Central Asia Tbk. Bengkulu branch
\end{abstract}

\section{Key Word: Employee Development, Job Performance}

\section{PENDAHULUAN}

Sumber daya manusia yang kompeten dan yang berkualitas sangat dibutuhkan untuk mendukung produktivitas dan aktivitas agar tujuan perusahaan atau suatu organisasi dapat tercapai dengan sempurna, oleh karena itu diperlukan pengembangan karyawan agar mutu dan kemampuan sumber daya manusia yang telah ada mampu bersaing dan dapat mengikuti perkembangan zaman, terlebih pada era globalisasi, dimana ilmu pengetahuan dan tekhnologi diberbagai bidang berkembang dengan sangat pesat. Pengembangan karyawan dirasakan semakin penting manfaatnya karena tuntutan pekerjaan atau jabatan, sebagai akibat kemajuan teknlogi dan semakin ketatnya persaingan diantara perusahaan yang sejenis.

Karyawan merupakan suatu aset yang penting bagi perusahaan untuk dapat mencapai tujuan yang telah di tentukan. Secara umum diperlukan adanya usaha untuk meningkatkan 
pengetahuan, pendidikan atau keterampilan, disiplin dan sikap mental para karyawannya pada tiap-tiap tingkatan secara terus menerus. Pesatnya perkembangan ilmu pengetahuan dan teknologi dewasa ini menimbulkan perkembangan dan pertumbuhan disegala aspek kehidupan yang berkaitan dengan adanya permasalahan baru yang sangat kompleks.

Seiring dengan arus era globalisasi maka metode-metode pengembangan karyawan harus menyesuaikan dan tepat sasaran, agar karyawan dapat berkembang sesuai dengan kebutuhan. Pengembangan perusahaan tidak lepas dari keberhasilan karyawannya dalam menjalankan roda perusahaan. Sayangnya, perkembangan perusahaan yang sangat pesat seringkali belum didukung oleh kesiapan para pemimpinnya. Hal ini dapat menyebabkan perusahaan kehilangan peluang bisnis yang seharusnya dapat diraih.

Pengembangan karyawan sendiri menurut Ranupandojo dan Husnan (2004:77) menyatakan pengembangan karyawan sering diartikan dengan usaha-usaha untuk meningkatkan keterampilan maupun pengetahuan umum bagi karyawan agar pelaksanaan pencapaian tujuan lebih efisien. Pada hakikatnya setiap perkembangan itu mengacu pada usaha dan kepuasan kerja agar tercapainya Prestasi kerja karyawan. Secara umum dapat dikatakan tingkat pendidikan seorang karyawan dapat mencerminkan kemampuan intelektual dan jenis keterampilan yang dimilikinya. Sudah menjadi kebiasaan dan hal yang umum bahwa jenis dan tingkat pendidikan seorang karyawan biasa di gunakan untuk mengukur dan menilai kemampuan seseorang, Prestasi kerja karyawan mengacu pada kualitas karyawannya.

Setiap personil dalam perusahaan dituntut agar dapat bekerja efektif, efisien, kuantitas dan kualitas pekerjaannya baik sehingga daya saing perusahaan semakin besar. Pengembangan ini dilakukan melalui pendidikan dan pelatihan. Untuk menunjang Prestasi kerja yang baik dari karyawan pada PT. Bank Central Asia Tbk. Cabang Bengkulu, diperlukan adanya pengembangan. Pengembangan dapat dilihat sebagai pertumbuhan kemampuan yang terjadi melampaui yang di tuntut dalam suatu pekerjaan, hal ini mewakili usaha-usaha untuk meningkatkan kemampuan karyawan untuk menangani berbagai jenis tugas pengembangan karyawan akan menciptakan kondisi dinamis di dalam organisasi, maka pada dasarnya karyawan yang telah mendapatkan kesempatan untuk mengikuti program pengembangan tersebut akan lebih mudah menyesuaikan diri pada perkembangan teknologi maupun sosial.

Setiap karyawan harus dapat berkembang dan mempunyai pengetahuan, kemampuan dan keterampilan yang memadai guna mencapai Prestasi kerja dan peningkatan karir yang secara langsung akan memajukan perusahaan. Dengan adanya pengembangan karyawan ini dapat mempengaruhi Prestasi kerja karyawan, sehingga akan dapat mencapai tujuan yang telah di tetapkan sebelumnya dengan tepat waktu dan efisien.

Kondisi pencapaian pengembangan karyawan yang terampil dalam segala bidang dalam organisasi menciptakan kondisi organisasi menjadi perusahaan yang sehat, dengan demikian kualitas kerja karyawan akan mendapat perhatian khusus. Karyawan yang terampil dan memiliki kemampuan dengan adanya pengembangan karyawan ini maka dapat mengerjakan tugas dengan cermat sehingga memberikan hasil yang baik. Hasil kerja yang baik berarti kualitas yang baik sehingga akan memberikan Prestasi kerja yang memuaskan kepada karyawan. Hal ini menjadi keuntungan sendiri bagi perusahaan atau organisasi tersebut.

\section{TINJAUAN LITERATUR Pengembangan Karyawan}

Pengembangan adalah suatu usaha untuk meningkatkan kemampuan teknis, teoritis, konseptual dan moral karyawan sesuai dengan kebutuhan pekerjaan/jabatan melalui pendidikan dan latihan. Pendidikan meningkatkan keahlian teoritis, konseptual dan moral karyawan sedangkan latihan bertujuan untuk meningkatkan keterampilan teknis pelaksanaan pekerjaan karyawan (Hasibuan, 2007:69).

Setiap perusahaan dirasa harus siap dan peka dalam menghadapi perubahan lingkungan organisasi perusahaan yang semakin cepat dan kompleks. Perusahaan yang dinamis akan berusaha mengantisipasi dan menyesuaikan diri terhadap segala pengaruh dari lingkungan organisasi, baik lingkungan makro maupun lingkungan mikro. Salah satu usaha untuk 
mengantisipasi perubahan lingkungan organisasi tersebut adalah dengan mengembangkan kualitas dan kemampuan sumberdaya manusia dalam organisasi melalui program pengembangan.

Mathis (2006:44) menjelaskan mengenai pengembangan yaitu usaha-usaha untuk meningkatkan kemampuan karyawan dalam lingkungan pekerjaan untuk menghadapi berbagai penugasan, sedangkan Ranupandojo dan Husnan (2004:77) menjelaskan dengan singkat bahwa pengembangan karyawan sering diartikan dengan usaha-usaha untuk meningkatkan keterampilan maupun pengetahuan umum bagi karyawan agar pelaksanaan pencapaian tujuan lebih efisien.

Menurut Moekijat dalam Sari (2009:32), pengembangan adalah usaha untuk memperbaiki pelaksanaan pekerjaan yang sekarang maupun yang akan datang dengan memberikan informasi, mempengaruhi sikap atau menambah kecakapan.

Menurut Hariandja (2002:220), latihan dan pengembangan dapat didefenisikan sebagai usaha yang terencana dan terorganisasi untuk meningkatkan pengetahuan, keterampilan, dan kemampuan karyawan dan secara konseptual dapat mempengaruhi sikap karyawan terhadap pekerjaan.

Beberapa penjelasan diatas memiliki kesimpulan bahwa pengembangan karyawan memiliki artian suatu usaha yang terencana dan sistematis untuk meningkatkan pengetahuan karyawan secara teknis, teoritis, konseptual dan moral sesuai dengan apa yang dibutuhkan perusahaan pada saat sekarang atau di masa mendatang dengan melalui pendidikan dan latihan.

\section{Tujuan Pengembangan Karyawan}

Pengembangan karyawan memiliki tujuan yang sangat bermanfaat baik bagi karyawan maupun perusahaan guna kemajuan perusahaan. Tujuan pengembangan karyawan menurut Hasibuan (2007:70) adalah sebagai berikut:

1. Produktivitas Kerja

Melalui pengembangan, produktifitas kerja karyawan akan meningkat, kualitas dan kuantitas produksi semakin baik, karena technical skill, human skill, dan managerial skill karyawan semakin baik

2. Efisiensi

Pengembangan karyawan bertujuan untuk meningkatkan efisiensi tenaga, waktu, bahan baku, dan mengurangi ausnya mesin-mesin, dan mengurangi pemborosan.

3. Kerusakan

Pengembangan karyawan bertujuan untuk mengurangi kerusakan barang, produksi, dan mesin-mesin karena karyawan semakin terampil dan ahli dalam melaksanakan pekerjaannya

4. Kecelakaan

Pengembangan bertujuan untuk mengurangi tingkat kecelakaan karyawan, sehingga jumlah biaya pengobatan yang dikeluarkan perusahaan berkurang

5. Pelayanan

Pengembangan bertujuan untuk meningkatkan pelayanan yang lebih baik dari karyawan kepada nasabah.

6. Moral

Dengan pengembangan, moral karyawan akan lebih baik karena keahlian dan keterampilan sesuai dengan pekerjaannya, sehingga mereka antusias untuk menyelesaikan pekerjaan dengan baik

7. Karier

Kesempatan untuk meningkatkan karier karyawan semakin besar, karena keahlian, keterampilan dan prestasi kerja lebih baik. Promosi ilmiah biasanya didasarkan kepada keahlian dan prestasi kerja seseorang

8. Konseptual

Manajer semakin cakap dan cepat dalam mengambil keputusan yang lebih baik, karena technical skill, human skill dan manajerial skillnya lebih baik 
9. Kepemimpinan.

Kepemimpinan seorang manajer akan lebih baik, human relationsnya lebih luwes, motivasinya lebih terarah sehingga pembinaan kerjasama vertikal dan horizontal semakin harmonis

10. Balas Jasa

Balas jasa (gaji, upah, insentif, dan benefit) karyawan akan meningkat karena prestasi kerja mereka semakin besar.

11. Konsumen

Memberikan manfaat yang baik bagi masyarakat konsumen karena mereka memperoleh barang atau pelayanan yang lebih bermutu.

Adapun prinsip-prinsip Pengembangan karyawan agar pengembangan karyawan menjadi baik menurut Soeprihanto (2005:88) antara lain :

1. Adanya dorongan motivasi dari trainer, misalnya persiapan transfer atau promosi.

2. Adanya laporan kemajuan (Program Report).

3. Adanya penguatan (Reinforcement).

4. Adanya partisipasi aktif dari trainer (Active Participation).

5. Latihan diberikan sebagian demi sebagian (Participle Of Learning).

6. Latihan harus mengingat adanya perbedaan individual (Individual differents).

7. Trainer yang selektif yaitu mau dan mampu.

8. Diusahakan training method yang sesuai.

Pengembangan dapat dilakukan melalui pendidikan dan pelatihan. Manulang (2001:56) mengatakan prinsip pendidikan dan pelatihan sebagai berikut :

1. Perbedaan Individu (Individual differences)

Perbedaan individu dalam latar belakang pendidikan, pengalaman, dan minat wajib diperhatikan saat merencanakan program pengembangan, khususnya dalam latihan dan pengawasan ataupun supervisory training. Latar belakang pendidikan dan pengalaman dapat menunjukkan perbedaan yang luas dan banyak artinya.

2. Hubungan dengan analisa jabatan (Relation to job analysis)

Pengembangan karyawan diumumkan dengan kebutuhan apa saja dalam suatu jabatan. Analisis jabatan dapat diartikan sebagai suatu kegiatan untuk mempelajari, mengumpulkan dan mencatat keterangan-keterangan atau fakta yang berhubungan dengan masing-masing jabatan secara sistematis dan teratur.

3. Data atau informasi yang diperoleh dari analisa jabatan dapat digunakan sebagai :

a. Mendapatkan karyawan yang tepat yang diperlukan untuk mencapai tujuan organisasi.

b. Mengadakan penilaian jabatan atau pekerjaan.

c. Menyusun program latihan.

d. Dasar untuk mengadakan kenaikan pangkat atau pemindahan.

e. Memperbaiki produktivitas karyawan.

5. Motivasi (Motivation)

Perhatian khusus diarahkan oleh seorang pemimpin dalam suatu perusahaan untuk memberikan motivasi karyawan dalam suatu program pengembangan. Dengan adanya motivasi terhadap karyawan memungkinkan dia untuk bekerja keras.

6. Partisipasi Aktif (Active Participation)

Partisipasi aktif dalam proses belajar mengajar akan dapat menambah minat dan semangat belajar. Sehubungan dengan itu, maka kebanyakan program pendidikan dan latihan berusaha mengarahkan peserta dalam pembicaraan-pembicaraan atau pernyataanpernyataan mengenai pandangan-pandangan mereka.

7. Pemilihan para pelatih (Selectim of Trainers)

Efektivitas dari kebanyakan program pengembangan secara langsung mencerminkan minat dan kemampuan pengajar daripada pelatih. Meskipun ada alasan-alasan untuk menunjuk pemimpin-pemimpin atau pengawas.

8. Latihan bagi para pelatih ( Training of Trainers ) 
9. Banyak pengawas, pemimpin baru dan manajemen puncak diminta untuk ikut serta memberikan latihan tanpa mempertimbangkan bahwa orangorang ini tidak mengetahui bagaimana harus mengajar. Oleh sebab itu pelatihan untuk para pelatih sangat penting dilakukan untuk menghindari kerugian yang mungkin terjadi pada masa yang akan datang.

10. Metode-metode Latihan (Training Methods)

Berbagai metode yang dapat digunakan untuk melatih para supervisor dan manajer. Metode yang umum digunakan adalah :
a. Metode Konferensi
b. Metode pemberian kuliah
c. Rotasi jabatan
d. Metode khusus
e. Proses Insiden
f. Metode Simulasi

11. Prinsip-prinsip Belajar (Principles of Learning) Para pelatih (Pengajar) harus mengetahui pentingnya minat belajar dan harus dapat mencegah kekacauan yang merintangi proses belajar.

Adapun metode pengembangan/development menurut Hasibuan (2007:80) meliputi :

1. Training Methods

Training methods merupakan metode latihan di dalam kelas yang juga dapat digunakan sebagai metode pengembangan (development) seperti rapat, studi kasus, ceramah dan role playing.

2. Under Study

Under Study adalah teknik pengembangan yang dilakukan dengan praktek langsung bagi seseorang yang dipersiapkan untuk menggantikan jabatan atasannya.

3. Job Rotation and Planned Progression

Job Rotation adalah teknik pengembangan yang dilakukan dengan cara memindahkan peserta dari suatu jabatan ke jabatan lainnya secara periodik untuk menambah keahlian dan kecakapannya pada setiap jabatan. Sedangkan Planned Progression sama dengan Job Rotation. Letak perbedaannya adalah setiap pemindahan tidak diikuti dengan kenaikan pangkat dan gaji, tetapi tugas serta tanggung jawab semakin besar.

4. Coaching and Counseling

Coaching adalah suatu metode pendidikan dengan cara atasan mengajarkan keahlian dan keterampilan kerja kepada bawahannya. Counseling adalah suatu cara pendidikan dengan melakukan diskusi antara pekerja dan manajer mengenai hal-hal yang sifatnya pribadi, seperti keinginannya, ketakutannya dan aspirasinya.

5. Junior Board of Executive or Multiple Management

Merupakan suatu komite penasihat tetap yang terdiri dari calon-calon manajer yang ikut memikirkan atau memecahkan masalah-masalah perusahaan untuk kemudian direkomendasikan kepada manajer lini (TopManagement). Komite penasihat ini hanya berperan sebagai staf.

6. Committee Assignment

Yaitu komite yang dibentuk untuk menyelidiki, mempertimbangkan, menganalisis, dan melaporkan suatu masalah kepada pimpinan

7. Business games adalah pengembangan yang dilakukan dengan diadu untuk bersaing memecahkan masalah tertentu.

8. Sensitivity Training Sensitivity Training dimaksudkan untuk membantu para karyawan agar lebih mengerti tentang diri sendiri, menciptakan pengertian yang lebih mendalam di antara para karyawan, dan mengembangkan keahlian setiap karyawan yang spesifik.

Sedangkan indikator-indikator pengembangan dalam hal pendidikan menurut Siagian (2003: 190) adalah:

1. Partisipasi, yaitu bagaimana Pelatihan diikuti oleh karyawan yang membutuhkan pelatihan untuk menunjang karirnya dalam perusahaan, selain itu juga dalam pelatihan terdapat pelatih yang ditugaskan untuk melakukan pelatihan terhadap peserta pelatihan. 
2. Materi pelatihan, yaitu hal-hal yang harus dipertimbangkan dalam perencanaan pelatihan pada karyawan. Materi pelatihan harus disiapkan dan disesuaikan dengan kebuthan pelatihan.

3. Tingkat kesulitan kerja, yang dimaksud disini adalah bagaimana Materi yang diberikan dalam pelatihan sesuai dengan kebutuhan karyawan yaitu kebutuhan peningkatan kemampuan dalam menghadapi kesulitan pekerjaan.

4. Transfer pengalihan, transfer yang dimaksudkan adalah pengalihan pengetahuan dari pelatih kepada peserta pelatihan yang nantinya akan bermanfaat dalam peningkatan kemampuan karyawan.

\section{Prestasi Kerja}

Menurut Hasibuan (2007 : 94) prestasi kerja adalah suatu hasil kerja yang dicapai seseorang dalam melaksanakan tugas-tugas yang dibebankan kepadanya yang didasarkan atas kecakapan, pengalaman dan kesungguhan serta waktu.

Menurut Sutrisno (2009 : 164), prestasi kerja adalah hasil kerja yang telah dicapai seseorang dari tingkah laku kerjanya dalam melaksanakan aktivitas kerja.Informasi tentang tinggi rendahnya prestasi kerja seseorang karyawan tidak dapat diperoleh begitu saja, tetapi diperoleksh melalui proses yang panjang, yaitu proses penilaian prestasi kerja karyawan yang disebut dengan istilah performance appraisal. Prestasi kerja merupakan gabungan dari tiga faktor penting yaitu kemampuan dan minat seorang pekerja. Semakin tinggi ketiga faktor di atas, semakin besarlah prestasi kerja karyawan bersangkutan.

Dalam konsep prestasi kerja perlu memperhatikan asas/prinsip-prinsip manajemen antara lain (Hasibuan, 2007 : 10) :

1) Adanya pembagian kerja/division of work yang jelas maksudnya adanya spesialisasi akan meningkatkan efisiensi dalam pelaksanaan kerja adanya spesialisasi akan meningkatkan efisiensi dalam pelaksanaan kerja.

2) Adanya wewenang yang jelas: maksudnya adanya hak untuk memberi perintah dan dipatuhi.

3) Disiplin, maksudnya harus ada respek dan ketaatan pada peranan-peranan dan tujuan organisasi.

4) Adanya kesatuan perintah dan kesatuan pengarahan maksudnya karyawan-karyawan hanya menerima intruksi dan pengarahan dari seorang atasan atau manajer sesuai bidang tugasnya, sehingga dalam pelaksanaannya jelas.

5) Melibatkan kepentingan perseorangan dibawah kepentingan umum maksudnya kepentingan perseorangan harus tunduk pada kepentingan organisasi.

6) Adanya balas jasa maksudnya adanya kompensasi pekerjaan yang dilaksanakan harus adil bagi semua karyawan.

7) Keadilan maksudnya harus ada kesamaan perilaku dalam organisasi.

8) Inisiatif maksudnya bawahan harus diberi kebebasan untuk menjalankan dan menyesuaikan rencananya walaupun beberapa kesalahan mungkin terjadi.

Menurut Syafei (13 Februari, 2009) dalam deroe.wordpress.com Aspek-aspek Prestasi Kerja yang dinilai dapat dikembangkan atau diperinci sehingga dapat membantu atau memudahkan dalam pelaksanaan penilaian, misalnya diperinci menjadi :

a) Kualitas hasil kerja : dimaksudkan untuk kepuasan konsumen

b) Kuantitas Pekerjaan : dimaksudkan untuk produktivitas yang tinggi.

c) Kemampuan bekerja sendiri : dimaksudkan untuk kemandirian.

d) Pemahaman dan pengenalan pekerjaan : dimaksudkan untuk mendapatkan hasil yang berkualitas.

e) Tanggung Jawab : dimaksudkan tanggung jawab seorang dan karyawannya dimulai dari perlakuan terhadap peralatan dan proses, serta material dan keselamatan kerja bagi orang lain. 


\section{Kerangka Analisis}

\begin{tabular}{|c|c|}
\hline Pengembangan Karyawan (X) & Prestasi Kerja ( Y) : \\
\hline 1. Partisipasi & 1. Kualitas hasil kerja \\
\hline 2. Materi pelatihan & 2. Kuantitas pekerjaan \\
\hline 3. Tingkat kesulitan kerja & 3. Kemampuan bekerja sendiri \\
\hline 4. Transfer pengalihan & $\begin{array}{l}\text { 4. Pemahaman dan pengenalan } \\
\text { pekerjaan }\end{array}$ \\
\hline
\end{tabular}

Gambar 1. Kerangka Analisis

\section{Hipotesis}

Hipotesis yang diajukan dalam penelitian ini adalah pengembangan karyawan mempunyai hubungan positif dan signifikan dengan Prestasi kerja pada PT. Bank Central Asia Tbk. Cabang Bengkulu “.

\section{HASIL PENELITIAN DAN PEMBAHASAN Karakteristik Responden}

Berdasarkan hasil kuesioner diketahui karakteristik karyawan pada PT. Bank Central Asia Tbk. Cabang Bengkulu meliputi jenis kelamin, usia, pendidikan dan masa kerja dapat dilihat pada tabel berikut ini :

Tabel 1. Karakteristik Responden Berdasarkan Jenis Kelamin

\begin{tabular}{|l|c|c|}
\hline \multicolumn{1}{|c|}{ Jenis Kelamin } & Jumlah (Orang) & Persentase \\
\hline Perempuan & 26 & $46 \%$ \\
\hline Laki-Laki & 30 & $54 \%$ \\
\hline Jumlah & 56 & $\mathbf{1 0 0} \%$ \\
\hline
\end{tabular}

Sumber: Hasil Kuesioner

Dari tabel 1 diketahui bahwa jumlah karyawan pada PT. Bank Central Asia Tbk. Cabang Bengkulu tidak jauh berbeda meskipun lebih besar jumlah karyawan laki-laki dengan jumlah karyawan sebanyak 54\%, sedangkan perempuan 46\%, artinya PT. Bank Central Asia Tbk. Cabang Bengkulu memiliki karyawan yang cukup berimbang antara laki-laki ataupun perempuan.

Tabel 2. Karakteristik Responden Berdasarkan Usia

\begin{tabular}{|l|c|c|}
\hline \multicolumn{1}{|c|}{ Usia } & Jumlah (Orang) & Persentase \\
\hline$>18$ Tahun & 14 & $25 \%$ \\
\hline$>25$ Tahun & 7 & $12 \%$ \\
\hline$>35$ Tahun & 35 & $63 \%$ \\
\hline Jumlah & 56 & $100 \%$ \\
\hline
\end{tabular}

Sumber: Hasil Kuesioner

Dari tabel 2 diketahui bahwa jumlah karyawan dengan usia $>35$ tahun adalah yang paling besar yaitu $63 \%$, setelah itu diikuti pada usia $>18$ tahun sebesar $25 \%$ dan yang terakhir adalah usia $>25$ tahun sebanyak 25\%, artinya PT. Bank Central Asia Tbk. Cabang Bengkulu memiliki karyawan yang telah berpengalaman dan memiliki pengetahuan yang lebih dari pengalaman karyawan tersebut. 
Tabel 3. Karakteristik Responden Berdasarkan Pendidikan

\begin{tabular}{|c|c|c|}
\hline Pendidikan & Jumlah (Orang) & Persentase \\
\hline SMA & 19 & $34 \%$ \\
\hline DIII & 1 & $2 \%$ \\
\hline SI & 34 & $61 \%$ \\
\hline SII & 2 & $3 \%$ \\
\hline Jumlah & 56 & $100 \%$ \\
\hline
\end{tabular}

Sumber: Hasil Kuesioner

Berdasarkan tabel 3 diatas maka dapat diketahui dengan jelas bahwa karyawan terbanyak adalah karyawan dengan pendidikan SI yaitu sebanyak 61\%, dan diikuti oleh karyawan dengan pendidikan SMA sebanyak 34\%, artinya PT. Bank Central Asia Tbk. Cabang Bengkulu memiliki karyawan yang memiliki pendidikan yang cukup untuk melaksanakan tugas yang diberikan, meskipun masih banyak pula karyawan yang memiliki pendidikan SMA.

Tabel 4. Karakteristik Responden Berdasarkan Masa Kerja

\begin{tabular}{|c|c|c|}
\hline Masa Kerja & Jumlah (Orang) & Persentase \\
\hline 1 s.d 10 tahun & 26 & $46 \%$ \\
\hline 11 s.d 20 tahun & 21 & $38 \%$ \\
\hline$>20$ tahun Jumlah & 9 & $16 \%$ \\
\hline Jun & $\mathbf{5 6}$ & $\mathbf{1 0 0} \%$ \\
\hline
\end{tabular}

Sumber: Hasil Kuesioner

Dari tabel diatas dapat diketahui bahwa karyawan terbanyak ada pada masa kerja 1 tahun sampai dengan 10 tahun, artinya karyawan pada PT. Bank Central Asia Tbk. Cabang Bengkulu memiliki karyawan yang terbilang baru dalam dunia kerja tetapi memiliki kemampuan yang baik dalam melaksanakan pekerjaan.

\section{Persepsi Responden Terhadap Variabel Pengembangan Karyawan dengan Prestasi kerja}

\section{a. Persepsi responden terhadap variabel pengembangan karyawan}

Untuk mengetahui pengembangan karyawan yang diberikan oleh PT. Bank Central Asia Tbk. Cabang Bengkulu, maka akan dilakukan analisis distribusi rata-rata berdasarkan hasil kuesioner yang telah diisi responden tentang pengembangan karyawan, pada tabel berikut :

Tabel 5. Distribusi Rata-Rata Persepsi Responden Terhadap Variabel Pengembangan Karyawan (X)

\begin{tabular}{|c|l|c|c|c|}
\hline No & \multicolumn{1}{|c|}{ Pernyataan } & Jumlah & $\begin{array}{c}\text { Rata- } \\
\text { rata }\end{array}$ & Keterangan \\
\hline 1 & $\begin{array}{l}\text { Karyawan yang ikut dalam pengembangan pelatihan aktif } \\
\text { dalam setiap kegiatan }\end{array}$ & 226 & 4,04 & Baik \\
\hline 2 & $\begin{array}{l}\text { karyawan mempunyai minat dalam mengikuti program } \\
\text { pengembangan }\end{array}$ & 230 & 4,11 & Baik \\
\hline 3 & karyawan memiliki kemauan untuk belajar & 220 & 3,93 & Baik \\
\hline 4 & materi pengembangan mengikuti perkembangan zaman. & 222 & 3,96 & Baik \\
\hline 5 & Materi pengembangan dapat diterapkan dalam pekerjaan & 221 & 3,95 & Baik \\
\hline 7 & Alat Peraga sesuai dengan kebutuhan pengembangan & 221 & 3,95 & Baik \\
\hline 8 & $\begin{array}{l}\text { Jenis pengembangan sesuai dengan kebutuhan pekerjaan yang } \\
\text { dimiliki masing-masing karyawan }\end{array}$ & 219 & 3,91 & Baik \\
\hline 9 & $\begin{array}{l}\text { tingkat kesulitan pengembangan sesuai dengan jabatan } \\
\text { instruktur memiliki wawasan yang luas terhadap materi yang } \\
\text { diajarkan }\end{array}$ & 217 & 3,88 & Baik \\
\hline 10 & $\begin{array}{l}\text { instruktur menyajikan materi pengembangan dengan cara yang } \\
\text { mudah dipahami }\end{array}$ & 209 & 3,73 & Baik \\
\hline & Rata-rata & 3,94 & Baik \\
\hline
\end{tabular}

Sumber: Hasil Kuesioner, diolah

$$
\begin{array}{lll}
\text { Keterangan: } & & \\
1,00-1,80 & =\text { Sangat Tidak Baik } & 3,41-4,20=\text { Baik } \\
1,81-2,60 & =\text { Tidak Baik } & 4,21-5,00=\text { Sangat Baik } \\
2,61-3,40 & =\text { Cukup Baik } &
\end{array}
$$


Dari tabel 5 tersebut untuk variabel pengembangan karyawan mendapatkan nilai rata-rata sebesar 3,94 berada pada interval 3,41 - 4,20 dengan kriteria baik, artinya pengembangan karyawan pada PT. Bank Central Asia Tbk. Cabang Bengkulu berjalan dengan baik, dan karyawan merasakan adanya perkembangan dalam segi kemampuan dalam menyelesaikan pekerjaan setelah dilakukannya pengembangan karyawan yang diadakan oleh PT. Bank Central Asia Tbk. Cabang Bengkulu.

Nilai rata-rata tertinggi pada variabel pengembangan karyawan ada pada pernyataan nomor 2 yaitu "karyawan mempunyai minat dalam mengikuti program pengembangan" artinya karyawan pada PT. Bank Central Asia Tbk. Cabang Bengkulu mempunyai minat/keinginan dalam setiap pengembangan pelatihan yang diadakan oleh PT. Bank Central Asia Tbk. Cabang Bengkulu, karyawan merasa dengan mengikuti setiap pelatihan pelatihan dalam program pengembangan karyawan yang dilakukan oleh PT. Bank Central Asia Tbk. Cabang Bengkulu maka karyawan dapat meningkatkan kemampuan dalam menyelesaikan tugas dengan baik dan benar sehingga Prestasi kerja karyawan pun meningkat.

\section{b. Persepsi responden terhadap variabel Prestasi kerja karyawan}

Adapun hasil dari kuesioner mengenai Prestasi kerja karyawan pada PT. Bank Central Asia Tbk. Cabang Bengkulu adalah sebagai berikut :

Tabel 6. Distribusi Rata-Rata Persepsi Responden Terhadap Variabel Prestasi kerja

\begin{tabular}{|c|l|c|c|c|}
\hline No & \multicolumn{1}{|c|}{ Pernyataan } & Jumlah & $\begin{array}{c}\text { Rata- } \\
\text { rata }\end{array}$ & Keterangan \\
\hline 1 & $\begin{array}{l}\text { Hasil dari pekerjaan karyawan PT. BCA Tbk. Cabang } \\
\text { Bengkulu telah sesuai dengan kebutuhan } \\
\text { penggunanya }\end{array}$ & 228 & 4,07 & Baik \\
\hline 2 & $\begin{array}{l}\text { Hasil dari pekerjaan karyawan PT. BCA Tbk. Cabang } \\
\text { Bengkulu telah sesuai dengan standar yang } \\
\text { ditetapkan }\end{array}$ & 232 & 4,14 & Baik \\
\hline 3 & $\begin{array}{l}\text { Hasil Pekerjaan sesuai dengan target yang telah } \\
\text { ditetapkan oleh PT. BCA Tbk. Cabang Bengkulu }\end{array}$ & 224 & 4,00 & Baik \\
\hline 4 & $\begin{array}{l}\text { Karyawan menyelesaikan pekerjaan dengan biaya } \\
\text { dan waktu yang telah ditetapkan dengan tepat }\end{array}$ & 228 & 4,07 & Baik \\
\hline 5 & $\begin{array}{l}\text { Karyawan dapat mengatasi kesulitan dalam } \\
\text { pekerjaan dengan mandiri }\end{array}$ & 223 & 3,98 & Baik \\
\hline 6 & $\begin{array}{l}\text { Tanpa bantuan yang berlebihan dari atasan } \\
\text { karyawan dapat memecahkan masalah dengan baik }\end{array}$ & 222 & 3,96 & Baik \\
\hline 7 & $\begin{array}{l}\text { Karyawan memiliki pengetahuan yang cukup dalam } \\
\text { pelaksanaan pekerjaan di PT. BCA Tbk. Cabang } \\
\text { Bengkulu }\end{array}$ & 222 & 3,96 & Baik \\
\hline 8 & $\begin{array}{l}\text { Pengetahuan dan kemampuan yang dimiliki oleh } \\
\text { karyawan PT. BCA Tbk. Cabang Bengkulu dapat } \\
\text { membuat karyawan mencapai kualitas hasil kerja } \\
\text { yang baik. }\end{array}$ & 218 & 3,89 & Baik \\
\hline 9 & $\begin{array}{l}\text { Karyawan PT. BCA Tbk. Cabang Bengkulu } \\
\text { bertanggung jawab atas pekerjaan }\end{array}$ & 221 & 3,95 & 3,77 \\
\hline 10 & $\begin{array}{l}\text { Karyawan PT. BCA Tbk. Cabang Bengkulu menjaga } \\
\text { dengan baik alat-alat kerja dengan baik }\end{array}$ & 211 & 38 \\
\hline Rata-rata
\end{tabular}

Sumber: Hasil Kuesioner, diolah

Keterangan:

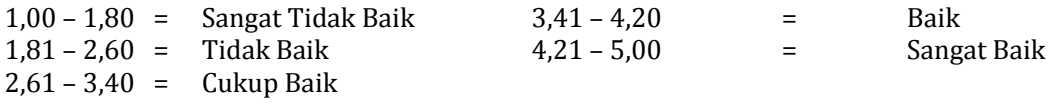

$3,41-4,20=$ Baik

Dari tabel 6 di atas untuk variabel Prestasi kerja mendapatkan nilai rata-rata sebesar 3,98 berada pada interval 3,41 - 4,20 dengan kriteria baik, artinya karyawan pada PT. Bank Central Asia Tbk. Cabang Bengkulu memiliki Prestasi kerja yang baik dalam perusahaan, 
terbukti dengan semua tugas yang diberikan dapat diselesaikan dengan baik dan benar oleh karyawan pada PT. Bank Central Asia Tbk. Cabang Bengkulu sehingga meningkatkan Prestasi kerja perusahaan.

Nilai rata-rata tertinggi adalah sebesar 4,14 dengan kriteria yang baik ini didapatkan oleh pernyataan nomor 2 yaitu "Hasil dari pekerjaan karyawan PT. BCA Tbk. Cabang Bengkulu telah sesuai dengan standar yang ditetapkan", ini artinya karyawan pada PT. Bank Central Asia Tbk. Cabang dalam bekerja memperhatikan dan berdasarkan standar yang telah ditetapkan oleh PT. Bank Central Asia Tbk. Cabang Bengkulu sehingga karyawan tidak menyimpang dari peraturan yang ada.

\section{Analisis Korelasi Spearman Rank}

Dari persepsi responden terhadap indikator penelitian baik variabel pengembangan karyawan maupun Prestasi kerja karyawan pada PT. Bank Central Asia Tbk. Cabang Bengkulu, maka dapat diketahui pengembangan dalam mengembangkan kemampuan dasar karyawan untuk dapat melaksanakan tugas yang diberikan sebaik-baiknya oleh karyawan dari PT. Bank Central Asia Tbk. Cabang Bengkulu maka akan dapat meningkatkan Prestasi kerja karyawan yang baik sehingga dapat meningkatkan Prestasi kerja perusahaan. Untuk mengetahui hubungan antara pengembangan karyawan (X) dengan Prestasi kerja karyawan (Y) PT. Bank Central Asia Tbk. Cabang Bengkulu, akan digunakan analisa deskriptif kuantitatif dengan pendekatan statistik (descriptive statistics) menggunakan korelasi spearman rank.

Dari tabel penolong untuk menghitung koefisien korelasi spearman rank pada lampiran 6 diketahui nilai-nilai, sebagai berikut:

$\sum \mathrm{bi}^{2}=2861$. selanjutnya nilai-nilai tersebut dianalisis untuk mengetahui hubungan pengembangan karyawan dengan Prestasi kerja karyawan pada PT. Bank Central Asia Tbk. Cabang Bengkulu:

$$
\begin{aligned}
& \rho=1-\frac{6 \sum b_{i}{ }^{2}}{n\left(n^{2}-1\right)} \quad \text { (Sugiyono, 2011:357) } \\
& \rho=1-\frac{6 \times 2861}{56\left(56^{2}-1\right)} \\
& \rho=1-\frac{17166}{56 \times 3135} \\
& \rho=1-\frac{171669}{175560} \\
& \rho=1-0,09 \\
& \rho=0,91
\end{aligned}
$$

Berdasarkan perhitungan koefisien korelasi, nilai $\rho$ hitung $=0,91$ artinya hubungan variabel pengembangan karyawan dengan Prestasi kerja adalah positif dan sangat kuat, karena nilai korelasi berada diantara interval koefisien $0.80-1.000$.

\section{Uji Hipotesis}

Dengan tingkat keyakinan $95 \%$ dan $\alpha$ (Alpha) $=0,05$ (5\%) maka dapat dilakukan pengujian hipotesis dengan menggunakan rumus thitung sebagai berikut :

$$
\begin{aligned}
& \mathrm{t}_{\text {hitung }}=\mathrm{rs} \sqrt{\frac{n-2}{1-r s^{2}}} \\
& \mathrm{t} \text { hitung }=0.91 \sqrt{\frac{56-2}{1-(0.91)^{2}}} \\
& \mathrm{t} \text { hitung }=0.91 \sqrt{\frac{54}{1-0,83}} \\
& \mathrm{t} \text { hitung }=0.91 \sqrt{\frac{54}{0,17}} \\
& \mathrm{t} \text { hitung }=0.91 \times 17,82 \\
& \mathrm{t} \text { hitung }=18,73
\end{aligned}
$$


Nilai $\mathrm{t}$ hitung $=18,73$ artinya $\mathrm{t}$ hitung lebih besar dari $\mathrm{t}$ tabel $=2.003$ atau berarti kesimpulan $\mathrm{HO}$ ditolak dan Ha diterima artinya ada hubungan signifikan antara pengembangan karyawan dengan Prestasi kerja pada PT. Bank Central Asia Tbk. Cabang Bengkulu.

\section{Pembahasan}

Berdasarkan perhitungan koefisien korelasi spearman rank, nilai $\rho$ hitung $=0,91$ artinya hubungan variabel pengembangan karyawan dengan Prestasi kerja karyawan adalah positif dan sangat kuat, karena nilai korelasi berada diantara interval koefisien 0,80 - 1.000 artinya hubungan kedua variabel sangat kuat.

Nilai $t$ hitung $=18,73$ artinya $t$ hitung lebih besar dari $t$ tabel $=2.003$ atau berarti kesimpulan $\mathrm{HO}$ ditolak dan Ha diterima artinya ada hubungan signifikan antara pengembangan karyawan dengan Prestasi kerja karyawan pada PT. Bank Central Asia Tbk. Cabang Bengkulu. Hal ini menunjukkan bahwa karyawan merasakan pengembangan karyawan yang dilaksanakan oleh PT. Bank Central Asia Tbk. Cabang Bengkulu berguna bagi karyawan guna mengembangkan kemampuan yang masih kurang, karyawan merasakan bahwa dengan adanya pengembangan yang baik dari perusahaan dalam meningkatkan kemampuan karyawan menjadi lebih baik lagi untuk menyelesaikan tugas-tugas yang diberikan oleh perusahaan maka pengetahuan yang dimiliki oleh karyawan menjadi lebih luas dan karyawan dapat dengan mudah menyelesaikan pekerjaan dan memecahkan masalah yang timbul selama proses pengerjaan tugas.

Setiap perusahaan dirasa harus siap dan peka dalam menghadapi perubahan lingkungan organisasi perusahaan yang semakin cepat dan kompleks. Perusahaan yang dinamis akan berusaha mengantisipasi dan menyesuaikan diri terhadap segala pengaruh dari lingkungan organisasi. Salah satu usaha untuk mengantisipasi perubahan lingkungan organisasi tersebut adalah dengan mengembangkan kualitas dan kemampuan sumberdaya manusia dalam organisasi melalui program pengembangan, begitu pula dengan PT. Bank Central Asia Tbk. Cabang Bengkulu sebagai perusahaan yang memiliki reputasi yang baik maka PT. Bank Central Asia Tbk. Cabang Bengkulu harus siap dalam menghadapi perubahan-perubahan yang ada dengan mengadakan pengembangan karyawan-karyawannya, sehingga karyawan mampu menyelesaikan tugas dengan sebaik-baiknya.

Seperti yang diketahui bahwa pengembangan adalah usaha yang terencana dan terorganisasi untuk meningkatkan pengetahuan, keterampilan, dan kemampuan karyawan dan secara konseptual dapat mempengaruhi sikap karyawan terhadap pekerjaan (Hariandja, 2002:220), maka dari itu dengan pengembangan yang baik oleh PT. Bank Central Asia Tbk. Cabang Bengkulu maka karyawan pada PT. Bank Central Asia Tbk. Cabang Bengkulu dapat meningkatkan pengetahuan, keterampilan, dan kemampuan karyawan dan bagaimana karyawan bersikap dalam lingkungan perusahaan, dengan karyawan memiliki kemampuan keterampilan, pengetahuan yang luas dan sikap yang baik dalam perusahaan maka karyawan akan meningkatkan Prestasi kerja.

Karyawan dapat menyelesaikan tugas dengan baik karena kemampuan pemahaman masalah yang dihadapi oleh karyawan selama proses penyelesaian pekerjaan baik, sehingga pekerjaan dapat terselesaikan dengan cepat oleh karyawan selain itu pekerjaan yang telah diselesaikan pun dikerjakan dengan benar dan akurat tanpa mengalami kesalahan sehingga harapan perusahaan dapat terwujud dengan baik oleh karyawan.

\section{Kesimpulan}

Dari hasil penelitian dan pembahasan maka dapat disimpulkan sebagai berikut:

1. Persepsi responden terhadap variabel pengembangan karyawan sebesar 3,94. Nilai tersebut berada diantara 3,41 - 4,20, berarti pengembangan sumber daya manusia yang diberikan kepada PT. Bank Central Asia Tbk. Cabang Bengkulu sudah baik. Persepsi tertinggi pada variabel pengembangan karyawan ada pada pernyataan nomor 2 yaitu "karyawan mempunyai minat dalam mengikuti program pengembangan" artinya karyawan pada PT. Bank Central Asia Tbk. Cabang Bengkulu mempunyai minat/keinginan dalam setiap pengembangan pelatihan yang diadakan oleh PT. Bank Central Asia Tbk. Cabang Bengkulu. 
2. Persepsi responden terhadap variabel Prestasi kerja sebesar 3,98. Nilai tersebut berada diantara 3,41 - 4,20, artinya Prestasi kerja karyawan PT. Bank Central Asia Tbk. Cabang Bengkulu sudah baik. Persepsi tertinggi terletak pada variabel Prestasi kerja terletak pada pernyataan pernyataan nomor 2 yaitu "Hasil dari pekerjaan karyawan PT. BCA Tbk. Cabang Bengkulu telah sesuai dengan standar yang ditetapkan", ini artinya karyawan pada PT. Bank Central Asia Tbk. Cabang dalam bekerja memperhatikan dan berdasarkan standar yang telah ditetapkan oleh PT. Bank Central Asia Tbk. Cabang Bengkulu sehingga karyawan tidak menyimpang dari peraturan yang ada

3. Dari perhitungan koefisien korelasi, nilai $\rho$ hitung $=0,91$ artinya hubungan variabel pengembangan dengan Prestasi kerja karyawan pada PT. Bank Central Asia Tbk. Cabang Bengkulu adalah sangat kuat, karena nilai korelasi berada diantara interval $0.80-1.000$.

4. Dari uji hipotesis diperoleh nilai t hitung lebih besar dari t tabel yaitu nilai $t$ hitung $=18,73$ sedangkan $\mathrm{t}$ tabel $=2,003$, artinya jika ada hubungan signifikan antara pengembangan dengan Prestasi kerja karyawan pada PT. Bank Central Asia Tbk. Cabang Bengkulu.

\section{Saran}

Pihak PT. Bank Central Asia Tbk. Cabang Bengkulu diharapkan selalu memperhatikan dan meningkatkan kebutuhan akan pengembangan sumber daya manusianya secara terus menerus atau berkesinambungan dan secara merata kesemua karyawannya sesuai dengan kebutuhan pekerjaan dan selalu mengikuti perkembangan zaman terutama di bidang perbankan agar Prestasi kerja karyawan pada PT. Bank Central Asia Tbk. Cabang Bengkulu terus meningkat.

\section{DAFTAR PUSTAKA}

Hasibuan, Malayu. S.P. 2007. Manajemen Sumber Daya Manusia. Jakarta: Bumi Aksara

Handoko, T. Hani. 2001. Manajemen Personalia dan Sumberdaya Manusia. Yogyakarta: BPFE

Manullang, M. 2001. Managemen Personalia. Jakarta: Aksara Baru.

Mangkunegara, Anwar Prabu 2000. Manajemen Sumber Daya Manusia Perusahaan. Bandung: PT Remaja Rosdakarya

Mathis, L. Robert. 2006. Manajemen Sumber Daya Manusia. Alih Bahasa

Sari, Irine Diana, 2009, Manajemen Pemasaran Usaha Kesehatan, Yogyakarta, Mitra Cendikia. -, 2009. Manajemen, Yogyakarta: Mitra Cendikia Press

Harianja, Marihot Tua Effendi. 2002 Manajemen Sumber Daya Manusia. Cetakan Pertama. Jakarta: Grasindo

Ranupandojo, Heidjrahman \& Suad Husnan. 2004. Manajemen Personalia. Yogyakarta: BPFE.

Siagian, Sondang. P. 2003. Organisasi, Kepemimpinan dan Perilaku Administrasi. Jakarta: Gunung Agung

Soeprihanto, TH Agung M. Harsiwi, Prakosa Hadi. 2005. Perilaku Organisasional. Yogyakarta: STIE YKPN

Sugiyono. 2011. Metode Penelitian Bisnis. Bandung: Alfabeta

Sutrisno, Edy. 2009, Manajemen Sumber Daya Manusia. Jakarta: Kencana 